Artikel Riset

DOI : 10.33751/jf.v8i1.1171
Fitofarmaka Jurnal Ilmiah Farmasi

Vol. 8, No.1, Juni $2018: 50-58$

p-ISSN : 2087-9164 e-ISSN : 2622-755X

\title{
MODE IKATAN METABOLIT SEKUNDER DI TANAMAN AKAR KUNING (Arcangelisia flava L.) DENGAN NITRAT OKSIDA SINTASE
}

\author{
Jennifer Kolina $^{1,2^{*}}$, Sri Adi Sumiwi ${ }^{2}$, Jutti Levita ${ }^{2}$ \\ ${ }^{1}$ Program Studi Magister Farmasi, Universitas Pajajaran,_Bandung 45363, \\ West Java, Indonesia \\ ${ }^{2}$ Departemen Farmakologi dan Farmasi Klinik, Universitas Padjadjaran,_Bandung \\ 45363, West Java, Indonesia \\ *E-mail: jenifer15001@unpad.ac.id
}

Diterima : 09 Maret 2018

Direvisi : 15 Maret 2018

Disetujui : 25 April 2018

\begin{abstract}
ABSTRAK
Inflamasi dapat menginduksi NOS (nitrat oksida sintase), yaitu enzim pengkatalisis pembentukan NO (nitrat oksida) berlebih sebagai pro-inflamasi. Akar kuning (Arcangelisia flava. L) banyak digunakan sebagai obat tradisional oleh masyarakat Asia Tenggara, baik sebagai obat luar maupun obat dalam. Senyawa kimia yang terkandung di dalam A. flava antara lain saponin, flavonoid dan tanin. Akar tanaman ini juga mengandung glikosida dan alkaloid, terutama golongan isokuinolin, yaitu berberin, jatrorizin dan palmatin. Terdapat juga beberapa alkaloid minor seperti kolumbamin, dehidrokoridalmin, homoaromolin dan talifendin, serta diterpen fibraleusin. Fibraurin berpontensi sebagai anti-bakteri, anti-tumor, dan anti-inflamasi. Tujuan penelitian ini adalah untuk menelaah mode ikatan senyawa-senyawa kimia yang terkandung dalam $A$. flava terhadap enzim NOS dengan metode penambatan molekuler menggunakan perangkat lunak AutoDock. Hasil penelitian menunjukkan bahwa berberin, daidzein, dehidrokorildamin, epikatekhin, hidroksiekdison, jatrorizin, kaempferol, piknarin, kuersetin, dan talifendin dapat berinteraksi dengan enzim NOS pada kantung aktif melalui pembentukan ikatan hidrogen dengan residu asam amino Glu377. Senyawa lainnya berinteraksi dengan residu asam amino tidak spesifik. Tidak ditemukan interaksi dengan Tyr347 pada semua senyawa. Hanya satu senyawa yang tidak membentuk interaksi dengan enzim NOS yaitu fibraurin.
\end{abstract}

Kata kunci: antiinflamasi, AINS, alkaloid, iNOS, metabolit sekunder.

\section{MODE OF BONDING COMPUNDS IN YELLOW ROOTS (Arcangelisia flava L.) WITH NOS ENZUMES FOR ANTIINFLAMMATORY}

\begin{abstract}
Inflammation can induce NOS (nitric oxide synthase), the enzyme catalyzing the formation of NO (nitric oxide) excess as pro-inflammatory. The yellow root (Arcangelisia flava. L) is widely used as a traditional medicine by the people of Southeast Asia as medicine for external and internal use. Chemical compounds contained in A. flava include saponins, flavonoids and tannins. The root of this plant also contains glycosides and alkaloids, especially groups of isokuinolin, i.e berberine, jatrorizin and palmatin. There are also some minor alkaloids such as kolumbamin,
\end{abstract}


dehidrokoridalmin, homoaromolin and talifendin, as well as fibraleucin. Fibraurin has the potential to be anti-bacterial, anti-tumor, and anti-inflammatory. The purpose of this study was to examine the bonding mode of chemical compounds contained in A. flava towards NOS enzymes using molecular docking method with AutoDock software. The results showed that berberine, daidzein, dehydrocorilineamine, epicatechin, hydroxyecdison, jatrorizine, kaempferol, piknarin, quercetin, and talifendin interact with NOS enzymes in the active site by forming hydrogen bonds with Glu377 amino acid residues. Other compounds interact with non-specific amino acid residues. No interactions with Tyr347 were found in all compounds. Only one compound that does not form an interaction with the NOS enzyme is fibraurin.

Keywords : antiinflamation, AINS, alkaloid, iNOS, secondary metabolite.

\section{PENDAHULUAN}

Terdapat beberapa mekanis-me terjadinya kerusakan jaringan dan proses perbaikan jaringan yang melibatkan proses pro-inflamasi dan antiinflamasi. Prostaglandin E2 (PGE2), transformasi growth factor- $\beta$, oksigen reaktif, dan nitrat oksida (NO) merupakan produk yang mengatur promosi inflamasi. Pada beberapa sel yang terlibat inflamasi seperti aktivasi makrofag, Nitrat Oksida diperlukan dalam proses fisiologi seperti vasodilatasi, neuro-transmisi, dan mempunyai sifat pertahanan sel. Nitrat oksida sintase) merupakan enzim yang menginduksi terbentuknya NO dimana NOS akan lebih banyak terproduksi ketika jumlah neutrofil dan makrofag meningkat. Inflamasi akan menginduksi NOS dan COX-2 yang akan menyebabkan peningkatan kadar NO dan PGE2 (Hussain, 2007).

Akar kuning (Arcangelisia flava. L) merupakan tumbuhan liana dan panjangnya dapat mencapai 20 meter. Di Indonesia, tumbuhan ini memiliki berbagai nama, antara lain tali kuning, oyod sirawan, dan katola (Artyani, 2014).

A. flava banyak digunakan sebagai obat tradisional oleh masyarakat Asia Tenggara, diantaranya untuk mengobati penyakit gangguan pencernaan dan sebagai anti-bakteri (Larisu, 2011). Di daerah Sulawesi Tenggara, rebusan batang A. flava digunakan sebagai antidiare yang signifikan khasiatnya. Senyawa kimia yang terkandung di dalam A. flava antara lain saponin, flavonoid dan tanin, di samping itu akarnya juga me-ngandung glikosida dan alkaloid, terutama golongan isokuinolin, yaitu berberin, jatrorizin, dan palmatin. Terdapat juga beberapa alkaloid min-or seperti kolumbamin dehidro-koridalmin, homoaromolin dan tali-fendin, serta diterpen fibraleusin, dan fibraurin memiliki beberapa aktivitas seperti antifungal, anti-asma, anti-bakteri, antitumor, anti-malaria dan anti-inflamasi (Singh et al., 2010). Lebih lanjut lagi, peneliti dari Taiwan melaporkan bahwa berberin, jatrorizin, dan palmitin terkandung di dalam ekstrak etanol Mahonia oiwakensis Hayata, terbukti menghambat inflamasi pada hewan uji yang diinduksi asam asetat, formalin, dan karagenan (Chao et al., 2013), namun mekanisme moleku-lernya tidak dilaporkan.

Interaksi senyawa-senyawa kimia didalam A. flava pada tingkat molekuler belum banyak dieksplorasi oleh karena itu penelitian ini memprediksi aktivitas anti-inflamasi senyawa-senyawa didalam A. flava melalui studi mode ikatannya dengan enzim NOS. 
METODE PENELITIAN

Alat dan Bahan

Komputer pribadi spesifikasi OS Windows 7 64-bit, processor AMD A6-6310 APU with AMD Radeon R4 Graphic $1.80 \mathrm{GHz}$, dan RAM 6 GB. perangkat lunak yang digunakan adalah ChemOffice 16.0.1 free trial (diunduh dari www.cambrigesoft.com), Open Babel 2.4.1 (diunduh dari www.openbabel.org), HyperChem Pro 8.0 (diunduh dari www.hyper.com), AutoDock dan AutoDock Vina (Molecular Graphics Laboratory) (diunduh dari www.autodock.scripps.edu), Ligand Explorer Viewer 4.1.0 (research collaborator for structural bioinformatics) diunduh dari www.pdb.org/pdb/explore, dan Discovery studio 2016 (diunduh dari http://accelyrs.com/products/).

Makromolekul iNOS yang digunakan pada penelitian ini diunduh dari situs Protein Data Bank http://www.rscb.org, diperoleh dari difraksi sinar- $X$ dengan resolusi $2,2 \AA$ (kode PDB 3E7G) dalam bentuk kompleks dengan ligan inhibitor ARC95791 dan molekul air (Garcin et al., 2008). Senyawa ligan digambar menggunakan ChemOffice 16, dioptimasi geometri menggunakan HyperChem Pro 8 dengan metode semi-empirik default setting.

\section{Persiapan Enzim NOS}

Enzim NOS dipisahkan dari inhibitor AR-C95791, dianalisis kantung ikatan dan interaksi ligan-reseptor. Tujuan dari analisis interaksi ligan dengan reseptor yaitu untuk mengetahui asam amino serta sisi farmakofor ligan yang berperan saat interaksi. Analisis ini dilakukan dengan menggunakan aplikasi Dis-covery Studio 2016 yang diunduh dari http://accelrys.com/products/.

\section{Persiapan Ligan dan Analisis Sifat Molekul}

Dalam penelitian ini digunakan 16 senyawa golongan alkaloid, 4 senyawa golongan fla-vonoid dan satu senyawa tanin. Senyawa tersebut antara lain berberine, palmatine, jatrorrhizine, columbamine, thalifendine, dehydrocorydalmine, pycnarrhine, limacine, homoaromoline, dihydroberberine, 20hydroxyecdysone, tetrandrine, fangchinoline, cepharanthine, sinoacutine, corydaline, kaempfrol, quercetine, epicatechin, daidzein dan triacontanyl caffeate.

Tahap awal yang dilakukan adalah menggambar struktur 2D dengan program ChemDraw 16 kemudian file tersebut disimpan dalam format cdx. Selanjutnya dilakukan optimasi geometri dan analisis sifat molekul masing-masing senyawa. Optimasi geometri dilakukan untuk menemukan konformasi yang paling sesuai dengan energi minimal suatu molekul untuk berikatan dengan molekul lainnya dengan menggunakan perintah MMFF94 yang akan melakukan optimasi secara otomatis. Struktur senyawa yang telah dioptimasi kemudian dianalisis sifat molekulnya dengan HyperChem dan disimpan dalam format file pdb. Tujuan dari analisis sifat molekul untuk mempelajari hubungan berbagai nilai kuantitatif terhadap aktivitas biologis molekul ligan. Terdapat beberapa parameter yang dapat diamati yaitu energi optimasi, volume, massa, koefisien partisi, serta potensial elektrostatik

\section{Validasi Perangkat Lunak}

Proses ini dilakukan untuk meminimalisir tidak validnya perangkat lunak pada saat melakukan penambatan molekul melalui parameter RMSD (Root Mean Square Deviation) yang mengukur kesamaan pose ligan asli dari struktur 
kristal dengan pose ligan hasil penambatan ulang. Suatu protokol dikatakan valid apabila penumpukan kedua pose mem-berikan nilai RMSD kurang dari dari $2 \AA$ (Istyastono, 2015)

\section{Penambatan Molekul Ligan Pada Kantung Aktif NOS}

Senyawa ligan yang telah digambar dan dioptimasi dirubah format filenya menjadi mol2 menggunakan program ChemOffice 3D 16 dan dikonversi menjadi pdbqt menggunakan menu konvert linux. File vina config yang didapatkan pada proses sebelumnya digunakan sebagai koordinat ligan saat proses docking senyawa. Selanjutnya proses penambatan ulang dilakukan dengan pengulangan sebanyak 50 kali. Parameter yang dilihat untuk evaluasi yaitu energi ikatan (EI), konstanta inhibisi
(KI), interaksi ikatan hidrogen dan residu asam amino.

\section{HASIL DAN PEMBAHASAN}

Residu asam amino penyusun kantung aktif enzim iNOS adalah Gln263, Arg266, Trp346, Tyr347, Pro350, Val352, Phe369, Asn370, Gly371, Trp372, Tyr373, Glu377, Asp382, dan Arg388. Pada struktur kristal iNOS tersebut dan hasil mutagenesisnya teridentifikasi ada-nya mode ikatan spesifik iso-enzim yang terhubung dengan serangkaian perubahan konformasi di dalam kan-tung ikatan baru. Plastisitas triad isoenzim-spesifik dari residu kulit kedua dan ketiga ternyata dapat memodulasi perubahan konformasional residu kulit pertama yang menentukan selektivitas inhibitor (Garcin et al., 2008).

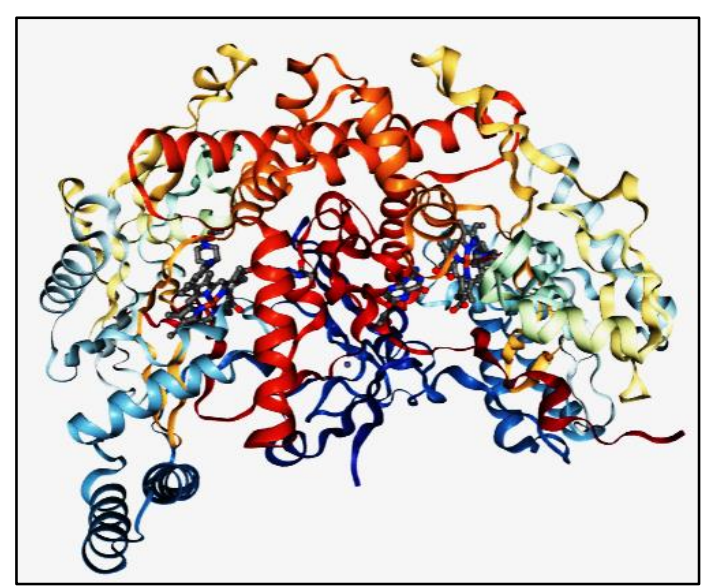

Gambar 1. Struktur 3D Enzim iNOS (kode PDB: 3E7G https://www.rcsb.org/structure/3E7G) 

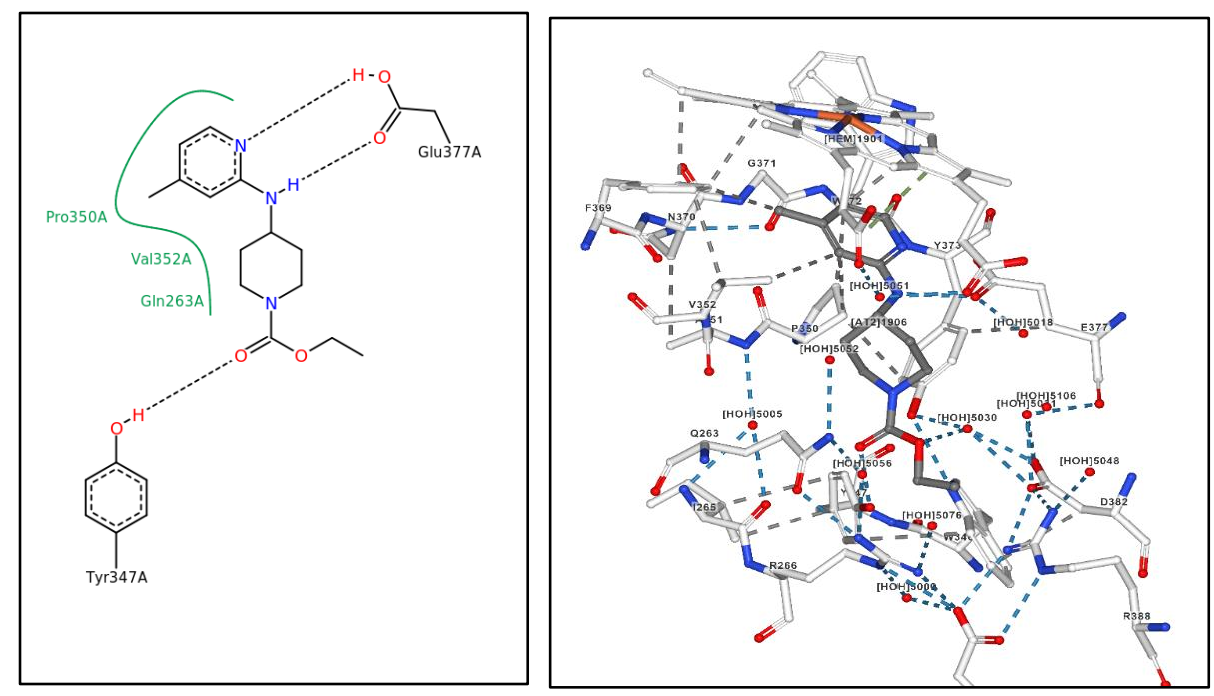

Gambar 2. Interaksi AR-C95791 dengan reseptor iNOS (Garcin et al., 2008)

Setelah itu reseptor dioptimasi dengan penambahan atom hidrogen (protonasi) yang bertujuan untuk menyesuaikan agar mendekati su-asana pada $\mathrm{pH}$ sitoplasma sel $(\mathrm{pH} 7)$ (Drie, 2005) dan melengkapi residu asam amino yang kehilangan atom hidrogennya dikarenakan adanya kemungkinan rusaknya struktur asam amino karena radiasi sinar X pada saat pengkristalan. Reseptor juga ditambahkan Kollman charges untuk memberikan muatan pada residu asam amino yang berupa energi potensial elektrostatik berdasarkan perhitungan mekanika kuantum.

Atom hidrogen yang diperhitungkan adalah yang bersifat polar, karena atom ini terlibat dalam ikatan hydrogen. Atom hidrogen non polar tidak disertakan dalam perhitungan interaksi ligan reseptor pada penambatan molekuler sehingga perlu digabung dengan atom pe-ngikatnya (Yanuar, 2012). Oleh karena itu dipilih pengaturan 'Merge Non-Polar'. Pada makromolekul juga dilakukan perbaikan muatan dengan menambahankan muatan gasteiger untuk menyesuaikan dengan ling-kungan penambatan molekul se-hingga dapat dilakukan perhitungan dengan benar (Huey et al., 2012). Selain itu diperlukan pengaturan grid box untuk menentukan ruang ko-ordinat ligan pada reseptor.

Ruang koordinat ligan diten-tukan dengan merujuk kepada pene-litian terdahulu berdasarkan ligan yang sudah tertambat dengan makromolekul protein pada saat diunduh, yakni AR-C95791. Pengaturan pada grid box yang digunakan meliputi center_x, center_y, center_z dan spacing (angstrom) $=1$ (Fikry, 2014). Kemudian reseptor disimpan dengan format (.pdbqt).

Gambar 2 menunjukkan bahwa inhibitor AR-C95791 berinteraksi membentuk dua buah ikatan hidrogen dengan Glu377 dan satu buah ikatan hidrogen dengan Tyr 347. Selain itu juga diamati adanya interaksi hidrofobik dengan Pro350, Val352, Gln263.

Hampir semua senyawa memiliki energi bernilai negatif. Energi ini merupakan energi global minimum. Dari 20 senyawa yang digunakan, 19 senyawa memiliki nilai lipofilisitas yang tinggi $(\log \mathrm{P}<5)$ (Tabel 1). Senyawa yang paling lipofilik dari 20 senyawa diatas adalah Tetrandin dengan nilai lipofilisitas 
$-4,61$. molekul obat tidak boleh terlalu hidrofil ataupun hidrofob karena akan menentukan tingkat kelarutan obat dalam air, terutama pada saat proses transfer ke situs aktifnya. Apabila obat terlalu hidrofob, obat akan terjerap dalam membran dan tidak akan mencapai situs aktivasinya.

\section{Hasil Validasi Perangkat Lunak Metode Overlay}

Gambar 3 menunjukkan hasil overlay AR-C95791 (AT2) dengan nilai RMSD 0,41 yang bermakna valid

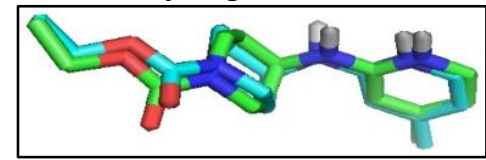

Gambar 3. Hasil overlay AR-C95791 (AT2)

Tabel 1. Hasil Persiapan Ligand dan Analisis Sifat Molekul

\begin{tabular}{clcccc}
\hline No & Nama senyawa & $\begin{array}{c}\text { Energi optimasi } \\
(\text { Kcal/mol) }\end{array}$ & $\begin{array}{c}\text { Massa } \\
(\mathbf{a m u})\end{array}$ & $\begin{array}{c}\text { Volume } \\
(\AA)\end{array}$ & Log P \\
\hline 1 & Berberin & -4303.4831 & 306.32 & 826.03 & -1.76 \\
2 & Jatrorizin & -4250.6050 & 296.32 & 815.30 & -1.40 \\
3 & Palmatin & -2949.8818 & 294.31 & 787.59 & -2.02 \\
4 & Kolumbamin & -4058.9081 & 278.31 & 780.94 & -0.99 \\
5 & Dihidroberberin & -4279.6505 & 309.32 & 832.37 & -2.97 \\
6 & Talifendin & -4319.6442 & 292.33 & 820.61 & 0.53 \\
7 & Homoaromolin & -7745.5219 & 524.62 & 1340.64 & -3.43 \\
8 & 20-hidroksiekdison & -5897.8888 & 346.51 & 1066.04 & 4.20 \\
9 & Triakontanil kafeat & -10423.3055 & 556.96 & 2081.14 & 12.46 \\
10 & Dehidrokoridalmin & -4339.9375 & 292.33 & 827.86 & -0.84 \\
11 & Piknarin & -2406.6981 & 162.19 & 517.34 & -0.12 \\
12 & Limasin & -8106.2754 & 544.65 & 1371.79 & -3.40 \\
13 & Tetrandrin & -5909.2926 & 566.65 & 1591.91 & -4.61 \\
14 & Fangkhinolin & -6658.1589 & 550.70 & 1422.74 & -1.21 \\
15 & Sefarantin & -6974.0606 & 608.73 & 1541.51 & -2.77 \\
16 & Sinoakutin & -3522.7213 & 315.37 & 883.57 & -1.03 \\
17 & Arkangelisia & -5607.8930 & 369.46 & 1073.72 & -1.98 \\
18 & Kaempferol & -3613.0757 & 286.24 & 741.49 & -2.99 \\
19 & Kuersetin & -3716.2967 & 302.24 & 760.55 & -4.01 \\
20 & Epikatekhin & -3860.7232 & 290.27 & 764.96 & -3.12 \\
21 & Daidzein & -3406.6141 & 254.24 & 707.22 & -1.03 \\
\hline
\end{tabular}




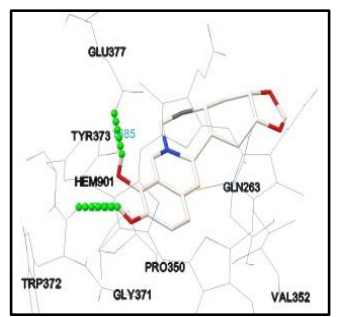

Berberin

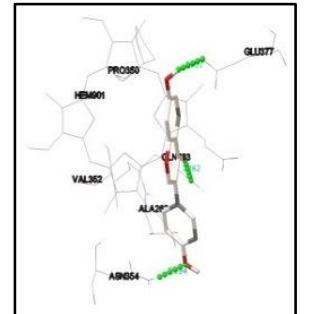

Daidzein

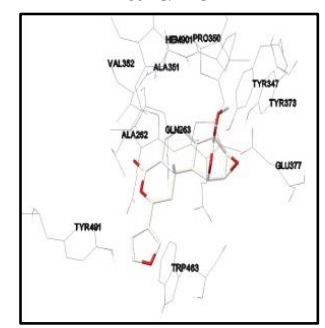

Fibraurin

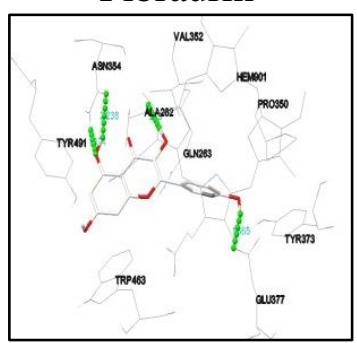

Kaempferol

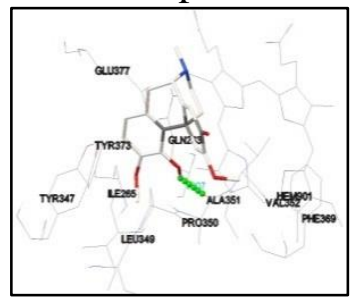

Sinoakutin

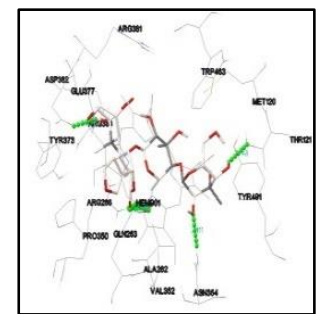

Arkangelisia

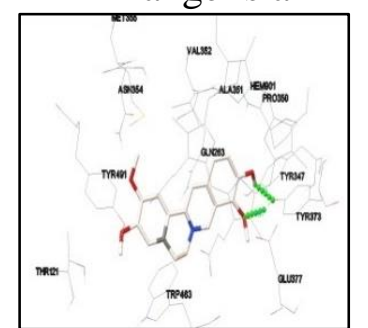

Dehidrokoridalmin

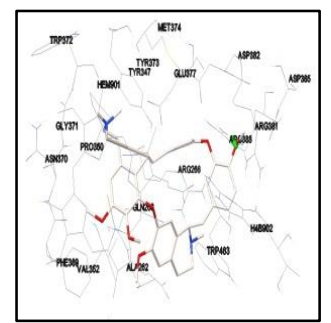

Homoaromolin

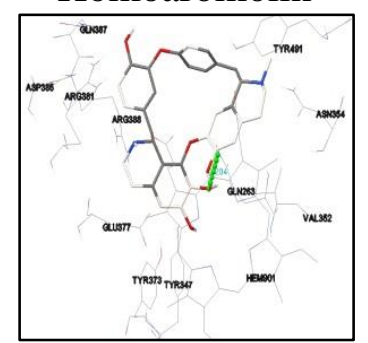

Limasin

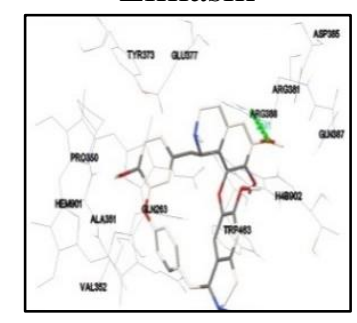

Tetrandrin

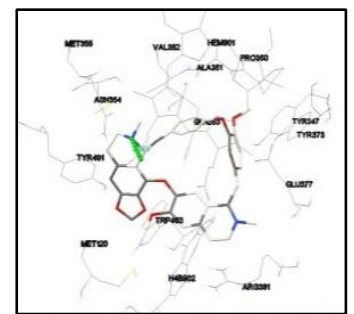

Sefarantin

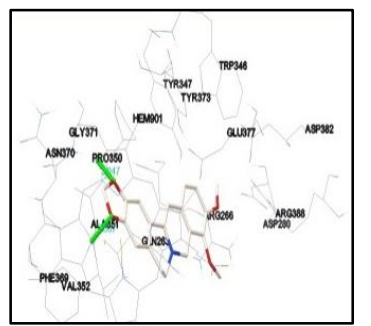

Dihidroberberin

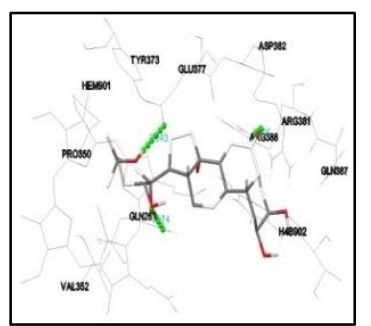

Hidroksiekdison

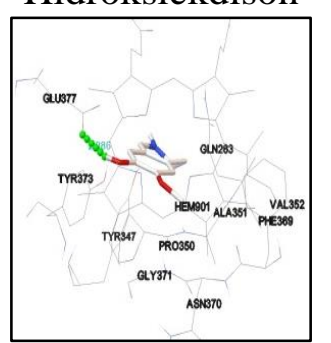

Piknarin

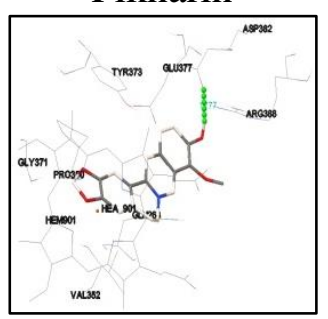

Talifendin

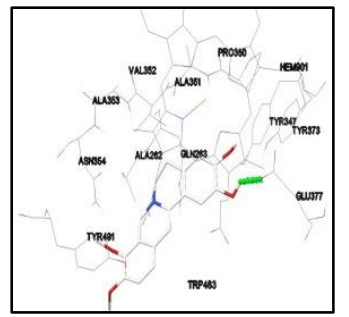

Kolumbamin

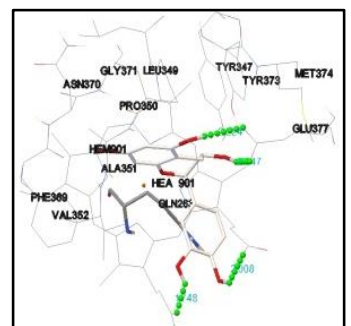

Epikatekhin

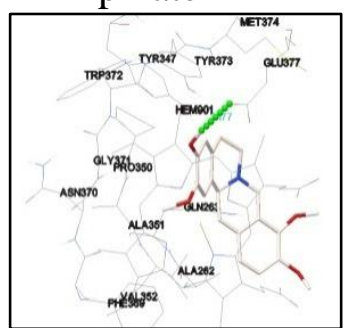

Jatrorizin

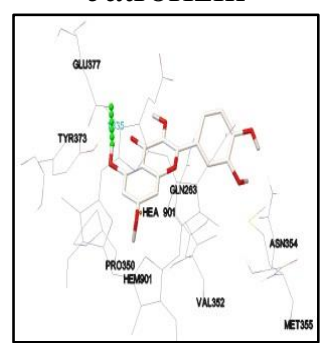

Kuersetin

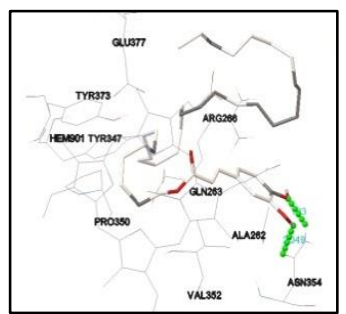

Triakontanil kafeat

Gambar 4. Hasil penambatan molekul 20 senyawa A. flava terhadap NOS

Dari hasil penambatan molekul 20 senyawa $A$. flava terlihat 10 senyawa (berberin, daidzein, dehidrokorildamin, epikatekhin, hidroksiekdison, jatrorizin, kaempferol, piknarin, kuersetin, dan talifendin) dapat berinteraksi dengan enzim NOS pada kantung aktif melalui pembentukan ikatan hidrogen dengan residu asam amino Glu377. Residu asam amino Glu377 pada iNOS manusia sama 
dengan Glu371 pada iNOS mencit. Residu Glu371 merupakan asam amino penting untuk berikatan dengan substrat (Alderton et al., 2001). Senyawa-senyawa lainnya di dalam akar kuning berinteraksi dengan residu asam amino tidak spesifik. Tidak ditemukan interaksi dengan Tyr347 pada semua senyawa. Hanya satu senyawa yang tidak membentuk interaksi dengan enzim NOS yaitu fibraurin.

\section{KESIMPULAN}

Senyawa-senyawa

hasil penambatan molekul yaitu berberin, daidzein, dehidrokorildamin, epikatekhin, hidroksiekdison, jatrorizin, kaempferol, piknarin, kuersetin, dan talifendin dapat berinteraksi dengan enzim nitrat oksida sintase pada kantung aktif. Ikatan hidrogen dengan residu asam amino Glu377. Senyawa lainnya berinteraksi dengan residu asam amino tidak spesifik. Tidak ditemukan interaksi dengan Tyr347 pada semua senyawa. Hanya satu senyawa yang tidak membentuk interaksi dengan enzim NOS yaitu fibraurin.

\section{REFERENSI}

Alderton, W.K., C.E. Cooper \& R.G. Knowles. 2001. Nitric oxide synthases: structure, function and inhibition. Biochem J. 357: 593-615

Artyani T. 2014. Efek antidepresan ekstrak larut air akar kuning Arcangelisia flava (L.) Merr pada mencit Balb-C ditinjau dari immobility time dengan metode forced swim test. Skripsi. Fakultas Farmasi Universitas Gadjah Mada.

Chao, J, J.W. Liao, W.H. Peng, M.S. Lee, L.H. Pao \& H.Y. Cheng. 2013. Antioxidant, analgesic, antiInflammatory, and hepatoprotective ffects of the ethanol extract of Mahonia oiwakensis stem. Int. J. Mol. Sci. 14: 2928-2945
Drie, J. H. 2005. Pharmacophore-based virtual screening: A practical perspective. In J. Alvarez dan B. Shoichet. Virtual Screening in Drug Discovery. CRC Press. FloridaUSA.

Fikry, M A. 2014. Studi penambatan molekul senyawa-senyawa flavonoid dari buah mengkudu (Morinda Citrifolia L) pada peroxisome proliferator-activated receptor-gamma (PPAR $\gamma)$. Skripsi, Program Studi Farmasi Fakultas Kedokteran dan Ilmu Kesehatan UIN Syarif Hidyatullah. Jakarta.

Huey, M.E., Forli, S., R., Pique, M. Sanner, D.S. Goodsell \& A.J. Olson. 2016. Computational protein-ligand docking and virtual drug screening with the AutoDock suite. Nature Protocols. 11(5): 905919.

Garcin, E. D., A. S. Arvai, R.J. Rosenfeld, M.D. Kroeger, B.R. Crane, B. R., G. Andersson \& E. D. Getzoff. 2008. Anchored plasticity opens doors for selective inhibitor design in nitric oxide synthase. Nat. Chem. Biol. 4(11): 700-707.

Hussain, S.P. \& C.C. Harris. 2007. Inflammation and cancer: an ancient link with novel potentials. Int. J. Cancer. 121: 2373-2380.

Istyastono, E.P. (2010). Seri Kimia Medisinal Komputasi: Langkah Praktis Docking Gratis, www.molmod.org. Yogyakarta.

Larisu, M. A. 2011. Kajian ilmiah air rebusan batang katola (Arcangelisia flava (L) Merr) obat tradisional diare berdarah masyarakat Kabupaten Muna Sulawesi Tenggara. Tesis. Program Pascasarjana Fakultas

Singh, A., S. Duggal, N. Kaur \& J. Singh. 2010. Berberin: alkaloid with wide 
spectrum of pharmacological activities. Journal of Natural Product 3: 64-75.

Yanuar, A. 2012. Penambatan Molekular Praktek dan Aplikasi Pada Virtual
Screening. Penerbit Fakultas Farmasi Universitas Indonesia. Depok. 